\section{$\underset{\substack{\text { hommes } \\ \text { \& migrations }}}{ }$}

\section{Hommes \& migrations}

Revue française de référence sur les dynamiques

migratoires

\section{$1297 \mid 2012$}

Migrations en création

\title{
Les femmes du bus 678
}

Film égyptien de Mohamed Diab

\section{André Videau}

\section{Q OpenEdition \\ 1 Journals}

Édition électronique

URL : http://journals.openedition.org/hommesmigrations/1334

DOI : 10.4000/hommesmigrations. 1334

ISSN : 2262-3353

Éditeur

Musée national de l'histoire de l'immigration

Édition imprimée

Date de publication : 1 mai 2012

Pagination : 167

ISSN : 1142-852X

\section{Référence électronique}

André Videau, «Les femmes du bus 678 », Hommes \& migrations [En ligne], 1297| 2012, mis en ligne le 29 mai 2013, consulté le 10 décembre 2020. URL : http://journals.openedition.org/ hommesmigrations/1334; DOI : https://doi.org/10.4000/hommesmigrations.1334

Ce document a été généré automatiquement le 10 décembre 2020.

Tous droits réservés 


\title{
Les femmes du bus 678
}

\author{
Film égyptien de Mohamed Diab
}

\section{André Videau}

La pratique du harcèlement sexuel (attouchements) dans les lieux publics favorisant la promiscuité, tels que les bien nommés "transports en commun", est, dans les villes égyptiennes et principalement au Caire, une sorte de passe-temps grivois, presque de sport national, de la part d'hommes de tous âges et de toutes conditions. Ils bénéficient de la complaisance des observateurs et des témoins, de la gêne des victimes, voire d'un sentiment vague de culpabilité. En cas de scandale avéré, ils étaient assurés de l'impunité. Jeune réalisateur trentenaire, Mohamed Diab a voulu dénoncer "ce fléau", sujet tabou, affirmant de la façon la plus effrontée la suprématie de l'homme (macho ou frustré) dès avant les bourrasques du printemps arabe qui allaient remettre en question nombre de conduites déviantes dans l'espace public. Tourné et sorti quelques mois avant les événements de la place Tahrir, le film peut être considéré comme un signe précurseur. Il remporte très vite un succès inhabituel et 2 millions de dollars pour 45 copies mises en circulation. Cela, un mois avant le déclenchement de la révolution! On peut au moins parler de télescopage. Trois jeunes femmes, Faysa (fonctionnaire issue d'un milieu pauvre) interprétée par la célèbre chanteuse Boushra, Seba, riche bourgeoise (Nelly Karim), et Nelly, jeune fille plus émancipée (Nahed El Sebaï), vont jouer leur partition dans ce film choral en déclenchant la révolte et des ripostes à la hauteur des outrages. Dans une dramaturgie sans surprise, elles vont affronter l'hostilité publique et l'opprobre qui entoure les actes qu'elles ont subis. La démonstration est un peu convenue, mais n'oublions pas que nous sommes en Égypte, pays englué dans des pudeurs séculaires, des hypocrisies tenaces et des pulsions sensuelles. Des attitudes, ailleurs anodines, peuvent ici déclencher le scandale, engendrer le drame. Ces passages à l'acte inversés se combinent avec "l'entrelac des parcours et des temporalités" qu'affectionne l'auteur, grand admirateur des constructions heurtées du mexicain Alejandro Inarritu. "Chez nous, le premier cadeau romantique qu'un homme donne à sa fiancée, c'est une bombe lacrymogène." Histoire de dire que les hommes sont aussi des victimes collatérales. Certains paieront la grossièreté du jeu du citron escamoté dans l'intimité d'une vraie tentative d'émasculation. Une autre force du film est de ne pas épargner les personnages masculins. L'atypique et ambigu commissaire 
Essam est ballotté entre les méandres de sa conscience, la rigueur implacable des faits et la dictature de l'opinion publique. Les incertitudes politiques qui ont suivi un printemps chaotique risquent de nous priver de films s'attaquant courageusement aux désordres sociaux. Ne gâtons pas notre plaisir devant la tentative de Mohamed Diab, quelles qu'en soient les simplifications. 